\title{
Konsumsi Antioksidan dan Ekspresi Gen eNOS3 Alel -786T $>C$ pada Penderita Hipertensi Etnik Minangkabau
}

\author{
Delmi Sulastri, N.I. Liputo \\ Bagian Gizi Fakultas Kedokteran Universitas Andalas
}

\begin{abstract}
Abstrak
Gen eNOS3 alel -786T>C merupakan salah satu gen yang berhubungan dengan kejadian hipertensi. Polimorfisme gen ini mengurangi kemampuan sintesis enzim nitric oxide synthase (NOS) sehingga sintesis nitric oxide (NO) menurun. Nitric oxide adalah senyawa vasoaktif yang menyebabkan vasodilatasi pembuluh darah. Penelitian bertujuan untuk melihat hubungan konsumsi antioksidan dengan ekspresi gen $e N O S 3$ alel $-786 T>C$ pada penderita hipertensi etnik Minangkabau. Cross sectional study dilakukan pada 130 subjek hipertensi dan normotensi berusia 30-65 tahun di 4 kecamatan kota Padang Sumatera Barat periode 2009. Wawancara konsumsi antioksidan menggunakan food frequency questioner, kemudian dilakukan pemeriksaan gen eNOS3 dengan polymerase chain reaction dan kadar NO plasma dengan enzyme linked immunosorbent assay. Data dianalisis menggunakan uji T dan chi-square. Hasil penelitian menunjukkan kadar NO plasma subjek hipertensi $26,91 \pm 15,40 \mu \mathrm{M} / \mathrm{L}$ dan normotensi $25,79 \pm 15,04 \mu \mathrm{M} / \mathrm{L}$. Substitusi thymine menjadi cytosine pada posisi 786 ditemukan sebanyak $1,5 \%$ pada kelompok hipertensi dan 9,2\% kelompok normotensi. Kadar NO plasma rendah (67,2\%) ditemukan pada subjek dengan alel heterozigot TC. Terdapat hubungan bermakna konsumsi antioksidan (vitamin E) dengan kadar NO plasma pada subjek hipertensi dengan alel heterozigot TC $(\mathrm{p}=0,03)$. Simpulan, terdapat hubungan konsumsi vitamin E dengan kadar NO plasma pada penderita hipertensi etnik Minangkabau yang memiliki alel heterozigot TC. [MKB. 2011;43(1):1-9].
\end{abstract}

Kata kunci: Alel -786T $>C$, etnik Minangkabau, gen eNOS3, hipertensi, kadar NO plasma

\section{Antioxidant Consumption and eNOS3 Gene -786T $>$ C Allel Expression in Hypertension Patients in Minangkabau Ethnicity}

\begin{abstract}
Gene of eNOS 3 allel -786T $>\mathrm{C}$ is one of the important genes which is related to the high prevalence of hypertension. Polymorphism of this gene decreases nitric oxide synthase (NOS) enzyme synthesis result in reduction of nitric oxide (NO). Nitric oxide causes vasodilatation, which decreases peripheral resistant and blood pressure. The aim of this study was to evaluate the influence of an antioxidant consumption on eNOS3 gene -786T $>$ C allel expression in hypertension patients with Minangkabau ethnicity. Cross sectional study was done on 130 hypertension and normotension subjects, 30-65 years old in 4 districts, Padang, Sumatera Barat during 2009. The interview about antioxidant consumption by food frequency questioner, the assessment of eNOS3 gene by polymerase chain reaction and NO plasma level by enzyme linked immunosorbent assay were done. The data were analyzed using t-test and chi-square. The results showed that the hypertensive's and normotensive's plasma NO concentration were $26.91 \pm 15.40 \mu \mathrm{M} / \mathrm{L}$ and $25.79 \pm 15.04 \mu \mathrm{M} / \mathrm{L}$, respectively. There were thymine to cytosine substitution found at 786 position in $1.5 \%$ of the hypertensive subjects and $9.2 \%$ of the normotensive subjects. A low plasma NO levels $(67.2 \%)$ was found in subjects with heterozygote TC alleles. There was a significant relationship between consumption of antioxidant (vitamin E) and NO plasma level in hypertension subjects with TC heterozygote allel. In conclusions, vitamin $\mathrm{E}$ influences NO plasma level in hypertension patients with heterozygote TC alleles. [MKB. 2011;43(1):1-9].
\end{abstract}

Key words: Allel of -786T $>$ C, eNOS3 gene, hypertension, Minangkabau ethnics, NO plasma level

Korespondensi: Dr. dr. Delmi Sulastri, Ms., Sp.GK, Bagian Gizi Fakultas Kedokteran Universitas Andalas, jalan Perintis Kemerdekaan PO Box 49 Padang (Sumatera Barat), telepon (0751) 39923, mobile 081363482291, faks (0751) 841886, e-mail:delmisulastri@yahoo.com 


\section{Pendahuluan}

Hipertensi suatu penyakit yang ditandai dengan peningkatan tekanan darah di atas nilai normal, dengan sistolik $>140 \mathrm{mmHg}$ dan atau diastolik $>90 \mathrm{mmHg}$ (Kriteria Join National Commiteel

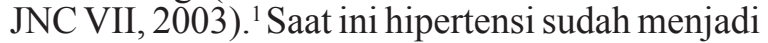
masalah utama kesehatan mesyarakat yang ada di Indonesia maupun di beberapa negara di dunia. ${ }^{2}$ Prevalensi hipertensi di seluruh dunia $15-20 \%$, sedangkan di Asia sudah mencapai 8-18\%. Pada tahun 2025 diperkirakan terjadi kenaikan kasus hipertensi sekitar $80 \%$, yaitu dari 639 juta kasus pada tahun 2000, menjadi 1,15 miliar pada tahun 2025. ${ }^{3}$ Prevalensi hipertensi di Indonesia 17$21 \%$, sedangkan Depkes RI (2007) melaporkan sudah mencapai $29.8 \% .{ }^{1}$ Prevalensi hipertensi di Sumatera Barat ternyata cenderung meningkat. Pada tahun 1977 prevalensi hipertensi hanya $7,3 \%,{ }^{2,4}$ sedangkan hasil riset kesehatan dasar yang dilakukan Departemen Kesehatan RI tahun 2007, prevalensi hipertensi di Sumatera Barat sudah mencapai 31,2\%. ${ }^{5}$ Sebanyak 95\% penderita hipertensi tidak diketahui penyebabnya dan dikenal sebagai hipertensi primer (esensial). Faktor utama yang berperan dalam patofisiologi hipertensi adalah interaksi faktor genetik dengan faktor lingkungan. ${ }^{6}$ Saat ini, paradigma biologi molekuler telah bergeser dari tekanan darah yang diregulasi oleh otak dan ginjal ke endotel. Endotel pembuluh darah dapat memproduksi relaxing factor yang mempunyai karakteristik sebagai gas vasoaktif, yaitu nitric oxide $(\mathrm{NO}){ }^{7}$

Gen eNOS3 adalah gen yang mengendalikan produksi NO. Salah satu polimorfisme gen yang sudah teridentifikasi berhubungan dengan kejadian hipertensi adalah $e N O S 3$ alel $-786 T>C{ }^{8}$ Beberapa penelitian yang telah dilaksanakan melaporkan bahwa polimorfisme gen eNOS3 menunjukkan faktor risiko yang berbeda antara etnik Asia dan non-Asia terhadap hipertensi. Etnik Asia dengan varian gen eNOS3 Glu298Asp dan $-786 T>C$ mempunyai faktor risiko hipertensi lebih rendah dibandingkan dengan non-Asia, sedangkan untuk intron $4 \mathrm{a} 4 \mathrm{~b}$ kedua etnik mempunyai faktor risiko yang sama. ${ }^{8}$ Polimorfisme Glu298Asp berhubungan nyata dengan terjadinya hipertensi esensial pada masyarakat Jepang. ${ }^{6}$ Penelitian yang sama juga dilakukan terhadap masyarakat Korea. Dari penelitian ini dilaporkan bahwa varian $-786 T>C$ dan intron $4 \mathrm{a} 4 \mathrm{~b}$ berhubungan bermakna dengan kejadian hipertensi. Individu dengan varian $-786 \mathrm{~T}>C$, terjadi penurunan respons gen terhadap asetilkolin dan kadar mRNA nitric oxide synthase (NOS), sedangkan nitrat darah lebih rendah dibandingkan dengan varian lain. ${ }^{8}$

Nitric oxide merupakan senyawa yang dapat menyebabkan relaksasi vaskular dan berperan sebagai regulator tonus otot polos melalui aktivasi soluble guanylate cyclase dan memperbaiki perfusi jaringan dengan menghambat adhesi dan agregasi trombosit serta adhesi leukosit pada permukaan sel endotel. ${ }^{7}$ Di samping itu NO secara tidak langsung dapat menyebabkan vasodilatasi pembuluh darah dengan menghambat pelepasan renin dan norepinefrin. ${ }^{7}$ Pada penderita hipertensi esensial, sintesis NO di bawah nilai basal (normal 25-45 $\mu \mathrm{M} / \mathrm{L}) .{ }^{6}$ Keadaan ini akan menyebabkan vasodilatasi pembuluh darah menurun sehingga terjadi peningkatan tahanan perifer. Penurunan kemampuan vasodilatasi pembuluh darah juga terjadi pada pembuluh darah di ginjal. Hal ini mengakibatkan penurunan glomerolus filtration rate (GFR), sistem renin angiotensin teraktivasi, dan akhirnya terjadi peningkatan tekanan darah. Nitric oxide yang berasal dari endotel dianggap senyawa yang bersifat ateroprotektif sehingga mengganggu sintesis $\mathrm{NO}$, dihubungkan dengan meningkatnya risiko penyakit kardiovaskular. ${ }^{6,8,9}$ Senyawa NO dalam darah dapat berikatan dengan homosistein membentuk senyawa S-NO-Hcy, hal ini mengakibatkan kadar homosistein darah menurun, dengan akibat risiko hiperhomosistein terhadap hipertensi akan berkurang. ${ }^{8}$

Pada penderita hipertensi, selain rendahnya kemampuan gen eNOS3 dalam mensintesis NO, asupan sayur-sayuran/buah-buahan yang rendah sebagai sumber antioksidan dapat menurunkan sintesis NO. Beberapa penelitian melaporkan bahwa asupan antioksidan seperti vitamin A, vitamin $C$, vitamin $E$, dan flavonoid yang cukup dapat meningkatkan aktivitas enzim NOS sehingga produksi NO akan meningkat. ${ }^{10-12}$ Etnik Minangkabau adalah masyarakat yang sebagian besar bertempat tinggal di Sumatera Barat. Beberapa penelitian melaporkan bahwa etnik Minangkabau mempunyai pola makan tinggi lemak jenuh dan rendah sayur-sayuran serta buahbuahan sebagai sumber antioksidan dan serat. Hatma $^{13}$ serta Delmi dkk. ${ }^{14}$ melaporkan asupan vitamin $\mathrm{C}$, vitamin $\mathrm{E}$, karotenoid, dan flavonoid pada subjek etnik Minangkabau masih di bawah angka kecukupan. Berdasarkan latar belakang yang telah diuraikan, maka dilakukan penelitian untuk mengetahui pengaruh konsumsi antioksidan pada ekspresi gen eNOS3 alel $-786 T>C$ pada penderita hipertensi etnik Minangkabau di kota Padang provinsi Sumatera Barat.

\section{Metode}

Penelitian ini merupakan studi komparatif dengan desain cross sectional study yang dilakukan di 4 kecamatan di kota Padang provinsi Sumatera Barat pada tahun 2009. 
Populasi diperoleh melalui penjaringan 800 calon subjek etnik Minangkabau (berdomisili di Sumatera Barat, kedua orangtua serta kakeknenek berasal dari Sumatera Barat) di empat kecamatan, yaitu kecamatan Padang Utara, Padang Barat, Pauh, dan Lubuk Kilangan. Setiap kecamatan dipilih dua kelurahan. Populasi adalah semua penderita hipertensi dan normotensi yang berusia 30-65 tahun. Subjek yang memenuhi kriteria inklusi dan tidak memenuhi kriteria eksklusi (hipertensi sekunder, diabetes melitus, dislipidemia, merokok, atlet, infeksi, postoperasi saluran cerna, dan menjalani diet) sebanyak 130 orang, terdiri atas 65 hipertensi esensial dan 65 subjek normotensi. Pengambilan subjek penelitian dilakukan dengan systematic random sampling.

Polimorfisme gen eNOS3 alel $-786 T>C$ diperoleh melalui ekstraksi DNA dari darah subjek dengan kit Promega, kemudian dilanjutkan dengan amplifikasi polymerase chain reaction (PCR) menggunakan primer $-786 T>C$ 5'ATGCT-CCCACCAGGGCATCA3'(sense) 5 ' G T C C T T GA G T C T GA C AT TA G G 3' (antisense) dan untuk menentukan adanya substitusi atau dilesi pada posisi 786, dilakukan restriction fragment polymorphism (RFLP) dengan enzim restriksi NaeI pada suhu inkubasi $37^{\circ} \mathrm{C}$ serta dielekroforesis menggunakan agarose 2,5\%. ${ }^{13}$ Enzim restriksi NaeI memiliki titik potong Blunt end pada GCG $\downarrow$ CGC. ${ }^{14}$ Hasil RFLP selanjutnya dikonfirmasi dengan hasil sekuensing (metode Sanger). Kadar NO plasma diperoleh dari hasil pemeriksaan $3 \mathrm{~mL}$ serum menggunakan enzyme linked immunosorbent assay (ELISA) dengan prinsip kerja bahwa nitrat dalam sampel darah akan direduksi oleh enzim nitrat reduktase menjadi nitrit dan direaksikan dengan reagen Griess untuk membentuk senyawa azo berwarna ungu, selanjutnya dibaca pada panjang gelombang 540-570 $\mathrm{nm}$. Konsumsi antioksidan satu tahun terakhir dinilai melalui wawancara menggunakan semiquantitative food frequency questioner (FFQ) dipandu dengan food model dan diolah menggunakan metode nutrisurvey. Setelah pengumpulan data lalu dianalisis menggunakan uji T untuk melihat perbedaan kadar NO plasma rerata dan asupan antioksidan. Uji chi-square untuk melihat pengaruh konsumsi antioksidan pada ekspresi gen eNOS3 alel $-786 T>C$.

\section{Hasil}

Enam puluh dua $(95,4 \%)$ subjek pada kelompok hipertensi berusia $>40$ tahun, wanita lebih banyak dibandingkan dengan laki-laki, yaitu 51 (78,5\%). Subjek dengan tingkat pendidikan rendah lebih banyak pada kedua kelompok, masing-masing $64,6 \%$ dan $56,9 \%$. Lebih dari separuh subjek tidak bekerja.

Ekspresi gen eNOS3 alel -786T $>C$ dinilai dari kemampuan gen tersebut untuk menghasilkan NO. Pada Tabel 1 dapat kita lihat kadar NO plasma rerata subjek studi. Kadar NO plasma rerata pada kedua kelompok hampir sama, yaitu kadar normal rendah $(25-45 \mu \mathrm{M} / \mathrm{L})$. Tidak terdapat perbedaan bermakna kadar NO plasma rerata antara kelompok hipertensi dan normotensi.

Polimorfisme gen eNOS3 diperoleh dengan

Tabel 1 Perbedaan Kadar NO Plasma Rerata pada Subjek Studi

\begin{tabular}{ccccccc}
\hline Kadar NO $(\boldsymbol{\mu M} / \mathbf{L})$ & $\mathbf{n}$ & Mean & SD & Min & Mak & Nilai p* \\
\hline Hipertensi & 65 & 26,91 & 15,40 & 6,00 & 66,00 & 0,68 \\
Normotensi & 65 & 25,79 & 15,04 & 9,00 & 67,50 & \\
\hline * Uji T & & & & & &
\end{tabular}

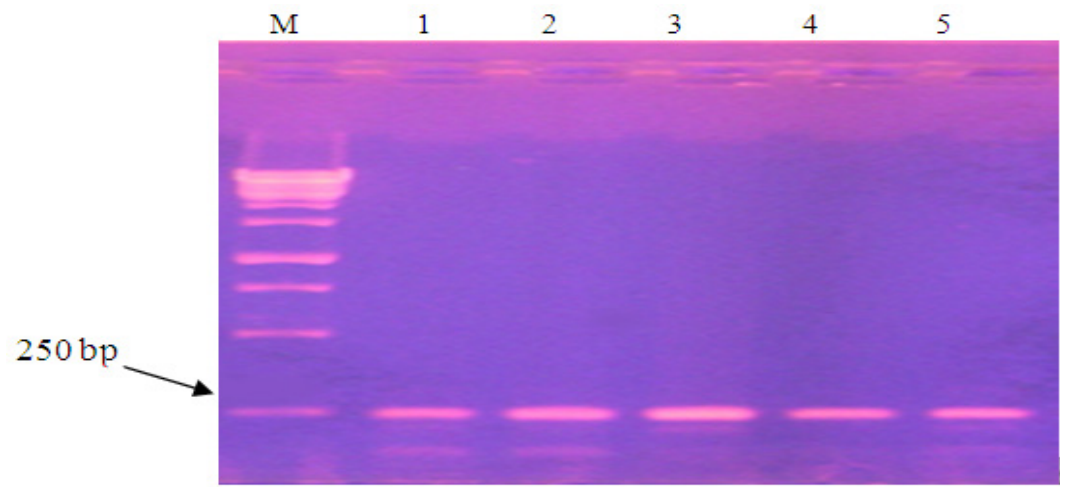

Gambar 1 Hasil PCR Gen eNOS3 alel -786T>C (M=Marker 1kb Ladder, 1-5 = Nomor Sampel) 


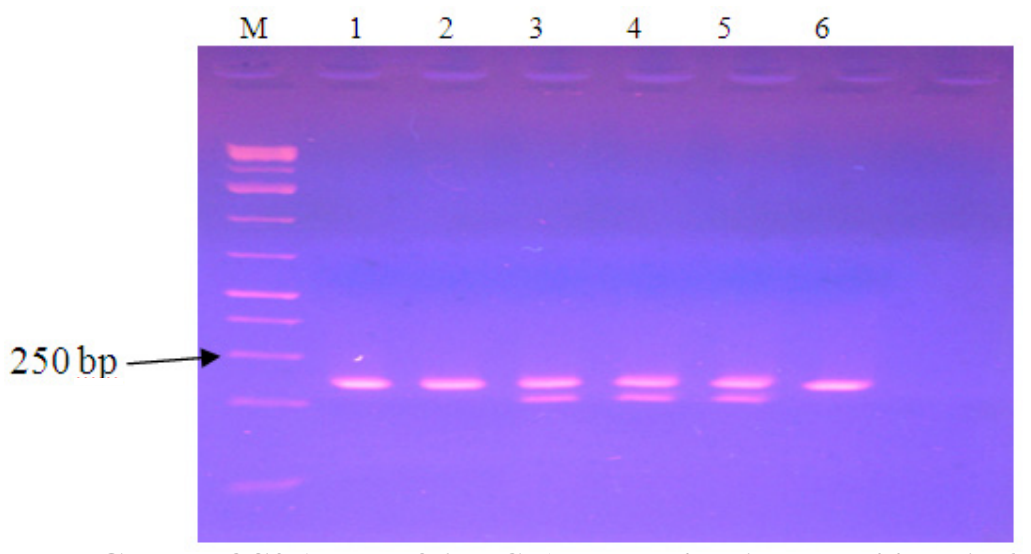

Gambar 2 Hasil RFLP Gen eNOS3 Alel -786T>C (M=Marker 1 kb Ladder, 1-6 Nomor Sampel)

mengekstraksi DNA dari $300 \mu \mathrm{L}$ darah subjek. Setelah didapatkan hasil DNA selanjutnya dielektroforesis menggunakan agarose 1\%. Hasil ekstraksi menunjukkan bahwa intensitas DNA yang diperoleh cukup baik, karena memiliki konsentrasi 3 kali lamda DNA atau $300 \mu \mathrm{L}$. DNA tersebut kemudian diamplifikasi menggunakan PCR, kemudian dilanjutkan dengan RLFP dan sekuensing. Gambar 1 adalah hasil amplifikasi DNA dengan menggunakan primer gen eNOS3 alel $-786 T>C$.

Gambar 1 juga menunjukkan hasil amplifikasi PCR pada 5 subjek studi. DNA hasil amplifikasi adalah DNA dari alel $-786 T>C$ dengan panjang fragmen 236 bp. Selanjutnya hasil amplifikasi tersebut dilakukan RFLP menggunakan enzim NaeI. DNA diinkubasi pada suhu $37^{\circ} \mathrm{C}$ selama 16 jam dan dilakukan elektroforesis menggunakan agarose 2,5\%.

Pada Gambar 2 dapat dilihat hasil restriksi enam sampel DNA dengan menggunakan primer $-786 T>C$. Sampel no 3, 4, dan 5 terbagi menjadi tiga fragmen berukuran masing-masing fragmen adalah 236 bp dan 203 bp, sedangkan fragmen yang panjangnya 33 bp tidak terlihat karena ukuran fragmen terlalu kecil. Dari hasil tersebut dapat disimpulkan bahwa sampel no 3, 4, dan 5 memiliki alel heterozigot TC karena hanya satu kromosom saja yang DNA-nya dapat dipotong oleh enzim restriksi. Pada sampel yang lain tidak terjadi pemotongan oleh enzim restriksi, artinya sampel tersebut mempunyai alel homozigot TT. Setelah semua tahapan di atas dikerjakan, didapatkan polimorfisme gen eNOS3 alel $-786 T>C$ (Tabel 2).

Tidak terdapat hubungan antara alel $-786 T>C$ dan kejadian hipertensi. Alel homozigot TT lebih banyak ditemukan pada kelompok kasus dibandingkan dengan alel homozigot $\mathrm{CC}$ dan heterozigot TC (Tabel 2).

Pada Tabel 3 terdapat hubungan bermakna antara asupan vitamin E dan kadar NO plasma pada kelompok kasus dengan alel heterozigot TC $(\mathrm{p}<0,05)$. Kadar NO plasma yang tinggi lebih banyak terdapat pada alel homozigot TT dengan asupan vitamin $\mathrm{C}$ kurang dan asupan vitamin E, retinol, karotenoid, serta flavonoid yang cukup. Pada alel heterozigot TC, kadar NO plasma yang tinggi lebih banyak ditemukan pada subjek dengan asupan vitamin $\mathrm{C}, \mathrm{E}$, retinol, dan karotenoid yang cukup kecuali asupan flavonoid.

Tabel 4 memperlihatkan hubungan asupan mikronutrien dengan kadar NO plasma pada kelompok normotensi. Kadar NO plasma yang tinggi lebih banyak ditemukan pada alel homozigot CC dengan asupan vitamin $\mathrm{C}$ dan flavonoid

Tabel 2 Distribusi Polimorfisme Gen $e N O S 3$ Alel -786T $>C$ pada Subjek Studi

\begin{tabular}{|c|c|c|c|c|c|}
\hline \multirow{3}{*}{ Alel } & \multicolumn{4}{|c|}{ Kelompok } & \multirow{3}{*}{ Nilai p* } \\
\hline & \multicolumn{2}{|c|}{ Hipertensi } & \multicolumn{2}{|c|}{ Normotensi } & \\
\hline & $\mathrm{n}$ & $\%$ & $\mathbf{n}$ & $\%$ & \\
\hline Homozigot TT & 42 & 64,6 & 45 & 69,2 & \\
\hline Homozigot CC & 1 & 1,5 & 6 & 9,2 & \\
\hline Heterozigot TC & 22 & 33,8 & 14 & 21,5 & 0,06 \\
\hline
\end{tabular}


Delmi Sulastri: Konsumsi Antioksidan dan Ekspresi Gen eNOS3 Alel -786T>C pada Penderita Hipertensi Etnik Minangkabau

Tabel 3 Hubungan Asupan Mikronutrien dengan Kadar NO Plasma berdasarkan Alel -786T $>C$ pada Kelompok Hipertensi

\begin{tabular}{|c|c|c|c|c|c|c|c|c|c|}
\hline \multirow{3}{*}{ Zat Gizi } & \multirow{3}{*}{ Alel } & \multirow{3}{*}{ Kategori } & \multicolumn{4}{|c|}{ Kadar NO Plasma $(\mu \mathrm{M} / \mathrm{L})$} & \multicolumn{2}{|c|}{ Total } & \multirow{3}{*}{ Nilai p } \\
\hline & & & \multicolumn{2}{|c|}{ Rendah } & \multicolumn{2}{|c|}{ Tinggi } & \multirow{2}{*}{$\mathbf{n}$} & \multirow{2}{*}{$\%$} & \\
\hline & & & $\mathbf{n}$ & $\%$ & $\mathbf{n}$ & $\%$ & & & \\
\hline \multirow{6}{*}{ Vitamin C } & \multirow{2}{*}{$\mathrm{CC}$} & Kurang & 0 & 0 & 0 & 0 & 0 & 0 & \multirow{5}{*}{0,10} \\
\hline & & Cukup & 1 & 100 & 0 & 0 & 1 & 100 & \\
\hline & \multirow{2}{*}{$\mathrm{TT}$} & Kurang & 2 & 40 & 3 & 60 & 5 & 100 & \\
\hline & & Cukup & 29 & 78,4 & 8 & 21,6 & 37 & 100 & \\
\hline & \multirow{2}{*}{$\mathrm{TC}$} & Kurang & 2 & 100 & 0 & 0 & 2 & 100 & \\
\hline & & Cukup & 12 & 60 & 8 & 40 & 20 & 100 & \multirow[t]{3}{*}{0,51} \\
\hline \multirow{8}{*}{ Vitamin E } & \multirow{2}{*}{$\mathrm{CC}$} & Kurang & 1 & 100 & 0 & 0 & 1 & 100 & \\
\hline & & Cukup & 0 & 0 & 0 & 0 & 0 & 0 & \\
\hline & \multirow{2}{*}{$\mathrm{TT}$} & Kurang & 23 & 76,7 & 7 & 23,3 & 30 & 100 & \multirow{3}{*}{0,69} \\
\hline & & Cukup & 8 & 66,7 & 4 & 33,3 & 12 & 100 & \\
\hline & \multirow{2}{*}{$\mathrm{TC}$} & Kurang & 9 & 90 & 1 & 10 & 10 & 100 & \\
\hline & & Cukup & 5 & 41,7 & 7 & 58,3 & 12 & 100 & $0,03 *$ \\
\hline & \multirow{2}{*}{$\mathrm{CC}$} & Kurang & 0 & 0 & 0 & 0 & 0 & 0 & \\
\hline & & Cukup & 1 & 100 & 0 & 0 & 1 & 100 & \\
\hline \multirow{4}{*}{ Retinol } & \multirow{2}{*}{$\mathrm{TT}$} & Kurang & 18 & 78,3 & 5 & 21,7 & 23 & 100 & \multirow{3}{*}{0,50} \\
\hline & & Cukup & 13 & 68,4 & 6 & 31,6 & 19 & 100 & \\
\hline & \multirow{2}{*}{$\mathrm{TC}$} & Kurang & 11 & 78,6 & 3 & 21,4 & 14 & 100 & \\
\hline & & Cukup & 3 & 37,5 & 5 & 62,5 & 8 & 100 & \multirow[t]{2}{*}{0,08} \\
\hline & $r C$ & Kurang & 0 & 0 & 0 & 0 & 0 & 0 & \\
\hline & $\mathrm{Cl}$ & Cukup & 1 & 100 & 0 & 0 & 1 & 100 & \\
\hline & & Kurang & 25 & 75,8 & 8 & 24,2 & 33 & 100 & \\
\hline Karotenoid & ТТ & Cukup & 13 & 59,1 & 9 & 40,9 & 22 & 100 & 0,19 \\
\hline & & Kurang & 4 & 100 & 0 & 0 & 4 & 100 & \\
\hline & $1 \mathrm{C}$ & Cukup & 3 & 60 & 2 & 40 & 5 & 100 & 0,44 \\
\hline & & Kurang & 1 & 100 & 0 & 0 & 1 & 100 & \\
\hline & $\mathrm{CC}$ & Cukup & 0 & 0 & 0 & 0 & 0 & 0 & \\
\hline & & Kurang & 21 & 80,8 & 5 & 19,2 & 26 & 100 & \\
\hline & $\mathrm{TT}$ & Cukup & 10 & 62,5 & 6 & 37,5 & 16 & 100 & 0,28 \\
\hline Flavonoid & & Kurang & 5 & 50 & 5 & 50 & 10 & 100 & \\
\hline & $\mathrm{TC}$ & Cukup & 9 & 75 & 3 & 25 & 12 & 100 & 0,38 \\
\hline
\end{tabular}

Keterangan: $\mathrm{TT}=$ Thymine Thymine $; \mathrm{CC}=$ Cytosine Cytosine $; \mathrm{TC}=$ Thymine Cytosine $;$ *Chi-square

cukup, tetapi dengan asupan vitamin E, retinol, dan karotenoid yang kurang. Untuk alel homozigot TT, kadar NO plasma yang tinggi lebih banyak ditemukan pada asupan vitamin $\mathrm{C}$ kurang dan asupan vitamin E, retinol, karotenoid serta flavonoid yang cukup. Pada alel heterozigot TC, kadar NO plasma yang tinggi lebih banyak pada asupan vitamin $\mathrm{C}$, retinol, karotenoid, dan flavonoid yang cukup, tetapi asupan vitamin E kurang.
Terdapat hubungan yang bermakna antara asupan vitamin E dan kadar NO plasma pada kelompok kontrol dengan alel homozigot TT.

\section{Pembahasan}

Kadar NO plasma rerata kelompok hipertensi adalah $26,91 \pm 15,40 \mu \mathrm{M} / \mathrm{L}$ dan kelompok normo- 
Tabel 4 Hubungan Asupan Mikronutrien dengan Kadar NO Plasma berdasarkan Alel -786 T>C pada Kelompok Normotensi

\begin{tabular}{|c|c|c|c|c|c|c|c|c|c|}
\hline \multirow{3}{*}{ Zat Gizi } & \multirow{3}{*}{ Alel } & \multirow{3}{*}{ Kategori } & \multicolumn{4}{|c|}{ Kadar NO Plasma $(\boldsymbol{\mu M} / \mathbf{L})$} & \multicolumn{2}{|c|}{ Total } & \multirow{3}{*}{ Nilai $\mathrm{p}$} \\
\hline & & & \multicolumn{2}{|c|}{ Rendah } & \multicolumn{2}{|c|}{ Tinggi } & \multirow{2}{*}{$\mathbf{n}$} & \multirow{2}{*}{$\%$} & \\
\hline & & & n & $\%$ & $\mathrm{n}$ & $\%$ & & & \\
\hline \multirow{6}{*}{ Vitamin C } & \multirow{3}{*}{$\mathrm{CC}$} & Kurang & 0 & 0 & 0 & 0 & 0 & 0 & \multirow{9}{*}{0,30} \\
\hline & & Cukup & 5 & 83,3 & 1 & 16,7 & 6 & 100 & \\
\hline & & Kurang & 4 & 36,4 & 7 & 63,6 & 11 & 100 & \\
\hline & TT & Cukup & 20 & 58,8 & 14 & 41,2 & 34 & 100 & \\
\hline & \multirow{3}{*}{$\mathrm{TC}$} & Kurang & 0 & 0 & 0 & 0 & 0 & 0 & \\
\hline & & Cukup & 11 & 78,6 & 3 & 21,4 & 14 & 100 & \\
\hline \multirow{9}{*}{ Vitamin E } & & Kurang & 4 & 80 & 1 & 20 & 5 & 100 & \\
\hline & \multirow[t]{2}{*}{$\mathrm{CC}$} & Cukup & 1 & 100 & 0 & 0 & 1 & 100 & \\
\hline & & Kurang & 13 & 54,2 & 11 & 45,8 & 24 & 100 & \\
\hline & TT & Cukup & 11 & 52,4 & 10 & 47,6 & 21 & 100 & \multirow[t]{2}{*}{0,90} \\
\hline & \multirow{3}{*}{$\mathrm{TC}$} & Kurang & 6 & 75 & 2 & 25 & 8 & 100 & \\
\hline & & Cukup & 5 & 83,3 & 1 & 16,7 & 6 & 100 & \multirow[t]{2}{*}{1,00} \\
\hline & & Kurang & 0 & 0 & 0 & 0 & 0 & 0 & \\
\hline & \multirow[t]{2}{*}{$\mathrm{CC}$} & Cukup & 5 & 83,3 & 1 & 16,7 & 6 & 100 & \multirow{4}{*}{0,00} \\
\hline & & Kurang & 13 & 81,3 & 3 & 18,8 & 29 & 100 & \\
\hline \multirow{3}{*}{ Retinol } & \multirow[t]{2}{*}{$\mathrm{TT}$} & Cukup & 11 & 37,9 & 18 & 62,1 & 16 & 100 & \\
\hline & & Kurang & 9 & 81,8 & 2 & 18,2 & 11 & 100 & \\
\hline & \multirow[t]{2}{*}{$\mathrm{TC}$} & Cukup & 2 & 66,7 & 1 & 33,3 & 3 & 100 & \multirow[t]{2}{*}{1,00} \\
\hline \multirow{9}{*}{ Karotenoid } & & Kurang & 1 & 50 & 1 & 50 & 2 & 100 & \\
\hline & \multirow[t]{2}{*}{$\mathrm{CC}$} & Cukup & 4 & 100 & 0 & 0 & 4 & 100 & \\
\hline & & Kurang & 11 & 78,6 & 3 & 21,4 & 31 & 100 & \multirow{3}{*}{$0,03^{*}$} \\
\hline & TT & Cukup & 13 & 41,9 & 18 & 58,1 & 14 & 100 & \\
\hline & & Kurang & 9 & 81,8 & 2 & 18,2 & 11 & 100 & \\
\hline & $\mathrm{TC}$ & Cukup & 2 & 66,7 & 1 & 33,3 & 3 & 100 & 0,57 \\
\hline & & Kurang & 3 & 100 & 0 & 0 & 3 & 100 & \\
\hline & $\mathrm{CC}$ & Cukup & 2 & 66,7 & 1 & 33,3 & 3 & 100 & \\
\hline & & Kurang & 18 & 62,1 & 11 & 37,9 & 29 & 100 & \\
\hline & TT & Cukup & 6 & 37,5 & 10 & 62,5 & 16 & 100 & 0,11 \\
\hline Flavonoid & & Kurang & 6 & 85,7 & 1 & 14,3 & 7 & 100 & \\
\hline & $\mathrm{TC}$ & Cukup & 5 & 71,4 & 2 & 28,6 & 7 & 100 & 1,00 \\
\hline
\end{tabular}

Keterangan: $\mathrm{TT}=$ Timin Timin $; \mathrm{CC}=$ Cytosine Cytosine $; \mathrm{TC}=$ Timin Cytosine; ${ }^{*}$ Chi-square

tensi $25,79 \pm 15,04 \mu \mathrm{M} / \mathrm{L}$. Hasil ini sesuai dengan kadar NO plasma normal $(25-45 \mu \mathrm{M} / \mathrm{L})$, tetapi pada kadar normal rendah. Tidak terdapat berbedaan bermakna kadar NO plasma antara kelompok hipertensi dan normotensi $(\mathrm{p}>0,05)$.

Kadar NO plasma normal yang rendah ini kemungkinan disebabkan oleh karena $\pm 50 \%$ subjek hipertensi maupun normotensi mempunyai alel homozigot CC dan heterozigot TC. Hal ini berarti pada alel homozigot CC sudah terjadi substitusi thymine menjadi cytosine, begitu juga pada alel heterozigot TC, sebagian kromosom sudah mengalami substitusi thymine menjadi cytosine. Keadaan ini menyebabkan respons gen tersebut terhadap stimulasi asetilkolin menurun sehingga produksi NO menurun. 
Gen eNOS3 merupakan gen yang terlibat dalam proses sistesis NO melalui sintesis enzim NOS, bekerja sebagai katalisator pembentukan NO dari asam amino arginin menjadi sitrulin. Pada polimorfisme tertentu kemampuan sintesis NO berkurang. Sampai saat ini sudah ditemukan beberapa polimorfisme pada gen eNOS3 yang berhubungan dengan penurunan sintesis NO. Setiap polimorfisme gen eNOS3 menunjukkan mekanisme yang berbeda terhadap sintesis NO dan fungsi endotel. Varian -786T>C adalah salah satu polimorfisme gen eNOS3 yang berhubungan dengan kejadian hipertensi. Pada alel $-786 T>C$ terjadi penurunan sintesis enzim NOS dan bioavailabilitas NO karena berkurangnya respons gen eNOS3 terhadap asetilkolin. ${ }^{7}$

Penelitian yang sama juga dilaporkan oleh Moriel dkk. ${ }^{15}$ pada 11 penderita hipertensi berusia $57,8 \pm 9,7$ tahun dan 11 pasien normotensi berusia $48,4 \pm 7,0$ tahun. Kadar NO penderita hipertensi sebesar $18,3 \pm 10,7 \mu \mathrm{M} / \mathrm{L}$ dan normotensi $20,7 \pm$ $16,0 \mu \mathrm{M} / \mathrm{L}$. Tidak terdapat perbedaan bermakna kadar NO plasma antara penderita hipertensi dan normotensi. Hasil penelitian ini berbeda dengan penelitian yang dilakukan oleh Kitanovska dkk. ${ }^{16}$ Penelitian dilakukan pada 26 wanita hipertensi usia $37,6 \pm 4,6$ tahun dan 11 wanita normotensi usia $35 \pm 6,7$ tahun. Kadar NO plasma wanita hipertensi secara bermakna lebih rendah bila dibandingkan dengan wanita normotensi dengan nilai median $22(11-35) \mu \mathrm{M} / \mathrm{L}$ pada hipertensi dan 37,5 (11-66) $\mu \mathrm{M} / \mathrm{L}$ pada normotensi. Perbedaan ini disebabkan karena subjek penelitian Kitanovska dkk. ${ }^{16}$ adalah wanita premenopause usia di bawah 40 tahun, sedangkan pada penelitian ini dilakukan pada kedua jenis kelamin dan lebih dari separuh subjek sudah berusia di atas 40 tahun. ${ }^{16}$

Usia dapat mempengaruhi kemampuan sel endotel untuk mensintesis NO. Pada usia lanjut kemampuan endotel pembuluh darah untuk menghasilkan NO sudah mulai berkurang. Kedua kelompok pada penelitian ini sebagian besar adalah wanita yang sudah menopause $(96,1 \%$ dan $84,3 \%$ ). Estrogen merupakan salah satu faktor yang dapat mempengaruhi kadar NO plasma. ${ }^{16}$

Alel -786T $>C$ pada kelompok hipertensi sebesar $1,5 \%$ dan normotensi $9,2 \%$, artinya pada posisi 786 terjadi substitusi DNA dari thymine menjadi cytosine. Polimorfisme gen eNOS3 alel $-786 T>C$ tidak mempunyai hubungan bermakna dengan hipertensi.

Pada penelitian Colombo dkk. ${ }^{9}$ dengan subjek orang Italia, bertujuan untuk melihat hubungan antara gen eNOS3 dan kejadian cardiovarcular diseases (CVD) pada 268 subjek hipertensi dan 147 subjek normotensi. Hasilnya didapatkan gen eNOS3 alel Glu298Asp mempunyai hubungan yang bermakna dengan kejadian hipertensi, tetapi sebaliknya tidak dengan alel $-786 T>C$. Hasil yang berbeda dilaporkan oleh Qi dkk. ${ }^{17}$ bahwa polimorfisme gen eNOS3 yang berhubungan dengan kejadian hipertensi adalah $-786 T>C$ dan intron 4a4b, tetapi Glu298Asp tidak berhubungan dengan kejadian hipertensi pada subjek orang Cina. Li dkk. ${ }^{18}$ juga melaporkan alel $-786 T>C$ berhubungan dengan kejadian hipertensi pada subjek Afrika Selatan.

Perbedaan hasil penelitian disebabkan karena masing-masing etnik mempunyai polimorfisme spesifik yang berhubungan dengan kejadian hipertensi. Selain perbedaan etnik, geografis dan jumlah subjek juga diduga sebagai faktor yang menyebabkan perbedaan tersebut. ${ }^{19}$

Vitamin $\mathrm{C}$ dan $\mathrm{E}$ merupakan mikronutrien yang dapat mempengaruhi kadar NO plasma. Vitamin $\mathrm{C}$ merupakan vitamin yang larut dalam air dengan angka kecukupan gizi yang dianjurkan $60 \mathrm{mg}$ /hari. Pada penelitian ini asupan vitamin C rerata pada kelompok hipertensi dan normotensi sebesar $150,06 \pm 85,45 \mathrm{mg} /$ hari dan $140,97 \pm 85,25$ $\mathrm{mg} /$ hari. Hasil ini lebih tinggi bila dibandingkan dengan penelitian Hatma ${ }^{13}$ yang mendapatkan median asupan vitamin C pada etnik Minangkabau sebesar $48,4 \mathrm{mg} /$ hari dan penelitian Delmi dkk. ${ }^{14}$ sebesar $35 \mathrm{mg} /$ hari.

Asupan vitamin E rerata adalah 14,65 $\pm 8,13$

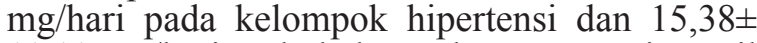
$11,11 \mathrm{mg} /$ hari pada kelompok normotensi. Hasil ini lebih tinggi dibandingkan dengan kecukupan yang dianjurkan $(10 \mathrm{mg} / \mathrm{hari})$ dan hasil yang dilaporkan oleh Hatma ${ }^{13}$ serta Delmi dkk. ${ }^{14}$ dengan nilai masing-masing $3,1 \mathrm{mg} /$ hari dan 0,5 $\mathrm{mg} /$ hari.

Pada penelitian ini tidak terdapat perbedaan bermakna asupan vitamin $\mathrm{C}$ dan $\mathrm{E}$ rerata pada kedua kelompok penelitian dan tidak terdapat hubungan asupan vitamin $\mathrm{C}$ dengan kadar NO plasma, baik pada kelompok hipertensi maupun normotensi. Terdapat hubungan positif bermakna asupan vitamin E dengan kadar NO plasma pada kelompok hipertensi dengan alel TC. Hasil ini berbeda dengan penelitian Livius dkk. ${ }^{11}$ yang dilakukan in vivo pada dua kelompok hewan percobaan. Pada kelompok pertama dipakai tikus normal, sedangkan kelompok kedua adalah tikus defisiensi apo E. Masing-masing kelompok diberi diet tinggi lemak dengan vitamin $\mathrm{C}$ atau E selama 26-28 minggu. Hasil penelitian ini menunjukkan bahwa suplementasi vitamin $\mathrm{C}$ jangka panjang secara bermakna meningkatkan aktivitas eNOS dan tidak mempengaruhi iNOS pada tikus normal, tetapi berpengaruh pada tikus defisiensi apo E. Efek vitamin $C$ terhadap aktivitas eNOS melalui kemampuan vitamin $\mathrm{C}$ dalam menstabilisasi $\mathrm{BH} 4$. 7,8-dihidrobiopterin dan memperbaiki fungsi endotel, sedangkan pemberian vitamin E jangka 
panjang tidak menimbulkan efek tersebut. ${ }^{11}$

Efek vitamin $\mathrm{C}$ dan $\mathrm{E}$ terhadap kadar NO plasma juga dilaporkan oleh Ulker dkk. ${ }^{12}$ Penelitian dilakukan pada tikus jantan berusia 20-22 minggu yang menderita hipertensi (Wistar hypertensive rats/WHR) dan normotensi (Wistar Kyoto rats/WKY). Pemberian NAD(P)H oksidase inhibitor secara bermakna dapat menurunkan produksi radikal superoksida. Inkubasi WHR dan WKY dengan vitamin $\mathrm{C}$ dan $\mathrm{E}$ dosis tinggi dapat memperbaiki fungsi endotel, menurunkan produksi superoksida sama baiknya dengan pemberian $\mathrm{NAD}(\mathrm{P}) \mathrm{H}$, meningkatkan aktivitas eNOS, dan regenerasi NO. Efek vitamin C dan E oleh karena kemampuan kedua vitamin tersebut sebagai antioksidan dan meregulasi superoksida dismutase (SOD). Efek kedua vitamin lebih tinggi bermakna pada WKY. Kemampuan vitamin C dan E memodulasi NAD(P)H dan aktivitas eNOS sampai saat ini belum diketahui secara pasti, tetapi diduga vitamin tersebut terlibat dalam proses transkripsi dan posttranslasi $\mathrm{NAD}(\mathrm{P}) \mathrm{H}$ oksidase dan eNOS. Vitamin E merupakan antioksidan lipofilik yang dapat memodulasi interaksi antara sitokrom b558, bagian membran yang berikatan dengan enzim $\mathrm{NAD}(\mathrm{P}) \mathrm{H}$ oksidase yang dapat mengaktivasi dan stabilisasi enzim. Vitamin E akan diambil oleh LDL sehingga memperbaiki fungsi endotel dengan menurunkan sensitivitas LDL terhadap proses oksidasi. Reaksi ini menjadi lebih kuat bila terdapat antioksidan lain seperti vitamin C. ${ }^{16}$

Hasil penelitian ini berbeda dengan penelitian Ulker dkk. ${ }^{12}$ dan Livius dkk. ${ }^{11}$ karena terdapat perbedaan usia, pendidikan, sosioekonomi, dan lingkungan subjek penelitian. Pola makan dapat dipengaruhi beberapa faktor seperti pendidikan, sosioekonomi, kultur, kebiasaan, dan lingkungan. Individu dengan sosioekonomi rendah cenderung memilih makanan tidak sehat seperti rendah sayur dan buah-buahan sebagai sumber antioksidan serta tinggi lemak. Penelitian pada penderita penyakit jantung koroner didapatkan asupan tinggi lemak total, serta rendah sayur dan buahbuahan lebih banyak ditemukan pada subjek tingkat pendidikan rendah. Buah-buahan dan sayur kurang memberi rasa kenyang dan harganya lebih mahal terutama buah-buahan. Keadaan ini menyebabkan individu tingkat pendidikan dan sosioekonomi rendah akan cenderung memilih makanan sebagai sumber energi yang dapat memberi rasa kenyang bila dibandingkan dengan memilih makanan sehat. Hal ini menyebabkan asupan vitamin $C$ kurang sehingga tidak dapat memberikan efek yang sama bila dibandingkan dengan kedua penelitian lainnya. ${ }^{14}$ Efek vitamin C sebagai antioksidan terjadi pada tingkat konsumsi yang lebih tinggi, yaitu $500-1.000 \mathrm{mg} /$ hari. ${ }^{20}$

Retinol dan karotenoid adalah antioksidan lipofilik.Padapenelitian inididapatkan asupanretinol rerata pada kelompok hipertensi dan normotensi sebesar $437,98 \pm 242,83 \mathrm{mg} /$ hari dan $536,80 \pm 914,97$ mg/hari, sedangkan asupan karotenoid rerata pada kedua kelompok adalah $6.123,25 \pm 4285,72 \mathrm{mg} /$ hari dan 3.893,63 $\pm 2.697,16 \mathrm{mg} /$ hari. Terdapat perbedaan bermakna asupan karotenoid antara kelompok hipertensi dan normotensi. Pada kelompok normotensi terdapat hubungan bermakna positif antara asupan retinol dan kadar NO plasma pada polimorfisme heterozigot GT. Pada kelompok hipertensi terdapat hubungan bermakna antara asupan karotenoid dan kadar NO plasma pada polimorfisme heterozigot GT.

All-trans retinoic acid (atRA) memiliki peranan yang penting dalam perkembangan dan maturitas sistem kardiovaskular. Pengaruh atRA terhadap kadar NO plasma sudah diteliti oleh Achan dkk. ${ }^{10}$ Penelitian dilakukan pada sel endotel murine yang telah diinkubasi dengan atau tanpa atRA. Hasilnya menunjukkan bahwa atRA secara bermakna dapat meningkatkan sintesis NO dan DDAH II, sedangkan peningkatan kadar NO plasma difasilitasi oleh DDHA II.

Pada penelitian ini asupan flavonoid rerata $117,14 \pm 60,23 \mathrm{mg} /$ hari pada kelompok hipertensi dan $101,51 \pm 46,08 \mathrm{mg} /$ hari pada normotensi. Flavonoid merupakan derivat polifenol dari diphenylpyrans yang ditemukan pada tumbuhtumbuhan. Senyawa ini berefek ateroprotektif, meliputi antioksidan sangat kuat, meningkatkan kemampuan trombosit untuk melepaskan NO, dan menghambat pembentukan trombus. Pemberian jus anggur selama 14 hari pada laki-laki sehat menyebabkan penurunan agregasi trombosit dan produksi radikal bebas serta meningkatkan sintesis NO. ${ }^{21}$

Simpulan, polimorfisme gen eNOS3 alel $-786 T>C$ tidak berhubungan dengan kejadian hipertensi pada etnik Minangkabau. Kadar NO plasma penderita hipertensi dan normotensi pada kadar normal rendah. Vitamin E dan karotenoid berhubungan positif dengan kadar NO plasma hanya pada penderita hipertensi dengan alel heterozigot TC. Konsumsi vitamin E dan karotenoid dapat meningkatkan kadar NO plasma hanya pada penderita hipertensi dan normotensi yang memiliki polimorfisme gen eNOS3 dengan alel heterozigot TC.

\section{Daftar Pustaka}

1. Seventh Report of the Joint National Committee on Prevention, Detection, Evaluation, and Treatment of High Blood Pressure (JNC 7), 
2003.

2. Armilawaty, Amalia H, Amiruddin. Hipertensi dan faktor risikonya dalam kajian epidemiologi. Makassar: Bagian Epidemiologi FKM Unhas; 2007.

3. Hadi H. Beban ganda masalah gizi dan implikasinya terhadap kebijakan pembangunan kesehatan nasional. Pidato Pengukuhan Jabatan Guru Besar. Yogyakarta: Fakultas Kedokteran UGM; 2005.

4. Boedi-Darmojo. Mengamati perjalanan epidemiologi hipertensi di Indonesia. Medika. 2001;XXVII(7):442-8.

5. Profil Kesehatan Provinsi Sumatera Barat. Padang: Dinas Kesehatan Provinsi Sumatera Barat; 2007.

6. Casas JP, Gianpiero L, Cavalleri GL, Bautista LE, Smeeth L, Humphries S. Endothelial nitric oxide synthase gene polymorphisms and cardiovascular disease. Circulation. 2002;106(3):388-91.

7. Palmer RMJ, Ferrige AG, Moncada S. Nitric oxide release accounts for the biological activity of endothelium derived relaxing factor. Nature. 1987;323:22-7.

8. Kim IJ, Bae J, Lim SW, Cha DH, Cho HG, Kim S. Influence of endothelial nitric oxide synthase gene polymorphisms $(-786>\mathrm{C}$, 4a4b, 894G $>\mathrm{T})$ in Korean patiens with coronary artery disease. Thrombo Res. 2007;119(15):579-85.

9. Colombo MG, Paradossi U, Andreassi MG, Botto N, Manfredi S, Masetti S, dkk. Endothelial nitric oxide synthase gene polymorphisms and risk of coronary artery disease. Clin Chemist. 2003;49:389-95.

10. Achan V, Tran CTL, Arrgoni F, Whitley GSJ, Leiper JM, Vallance PA. All-trans-retinoic acid increases nitric oxide synthesis by endothelial cells. Circ Res. 2002;90:764.

11. Livius VD, Milstien S, Richardson D, Smith L, Katusic ZS. Long term vitamin C treatment increases vascular tetrahydrobiopterin levels and nitric oxide synthase activity. Circ Res. 2003;92:88.

12. Ulker S, McKeown PP, Bayraktutan U. Vitamins reverse endothelial dysfunction through regulation of eNOS and $\mathrm{NAD}(\mathrm{P}) \mathrm{H}$ oxidase activities. Hypertension. 2003;41:
534.

13. Hatma RD. Nutrient intake and their relation to lipid profile in diverse ethnic population (Disertasi). Jakarta: Post Graduate Program, University of Indonesia; 2002.

14. Delmi S, Rahayu S, Astuty P. Pengaruh pola makan terhadap profil lipid dan MDA plasma laki-laki etnik Minangkabau. MKI. 2004;32:1-5.

15. Moriel P, Sevanian A, Ajzen S, Zanella MT, Plavnik FL, Rubbo H, dkk. Nitric oxide, cholesterol oxides and endothelium dependent vasodilation in plasma of patients with essential hypertension. Braz J Med Biol Res. 2002;35(11):1301-9.

16. Kitanovska BG, Zahrovska K, Bogdanovska S, Lozance L, Andreevska GS. Decreased nitric oxide tin women with essential hypertension in pre hypertension phase. Croat Med J. 2005;46(6):889-95.

17. QiZ, Shao-yong S, Shu-feng C, Biao L, Dongfeng G. Association study of the endothelial nitric oxide synthase gene polymorphisms with essensial hypertension in northern Han Chinese. Chinese Med J. 2006;13:1065-71.

18. Li R, Lyn D, Lapu-Bula R, Oduwole A, Igho-Pemu P, Lankford B, dkk. Relation of endothelial nitric oxide synthase gene to plasma nitric oxide level, endothelial function, and blood pressure in African American. Am J Hypertens. 2004; 17:560-7.

19. Kato N, Sugiyama T, Morita H, Nabika T, Kurihara H, Yamori Y, dkk. Lack of evidence for association between the endothelial nitric oxide synthase gene and hypertension. Hypertension. 1999;33:933-6.

20. Harrats D, Chevion S, Nahir M, Norman Y, Sagee, Berry EM. Citrus fruit supplementation reduces lipoprotein oxidation in young men ingesting a diet high in saturated fat; presumptive evidence for en interaction between vitamins $\mathrm{C}$ and $\mathrm{E}$ in vivo. Am $\mathrm{J}$ Nutr. 1998;67:240-5.

21. Freedman JE, Parker C, Li L, Perlman JA, Frei $\mathrm{B}$, Ivanov $\mathrm{V}$, dkk. Select flavonoids and whole juice from purple grapes inhibit platelet fuction and enhanced nitric oxide release. Circulation. 2001;103:1-17. 